\title{
PENGARUH UKURAN PERUSAHAAN, LABA/RUGI PERUSAHAAN,KOMPLEKSITAS OPERASI PERUSAHAAN, DAN REPUTASI KAPTERHADAP AUDIT DELAY PADA PERUSAHAANPERTAMBANGAN
}

\author{
Jessica Tricia \\ Institut Bisnis dan Informatika Kwik Kian Gie \\ Prima Apriwenni \\ Institut Bisnis dan Informatika Kwik Kian Gie \\ Prima.apriwenni@kwikkiangie.ac.id
}

\begin{abstract}
The background of this research there were inconsistent results on the variables that affect audit delay. Besides that, in 2015 several companies suspended by the Stock Exchange because of late financial reports. This study aimed to research the influence of company size, company's profit/loss, company's operations complexity and reputation of public accountant firm on audit delay. This study has done at mining companies listed in Indonesian Stock Exchange during the period 2012-2014. The sampling method used purposive sampling and obtained 96 as total sample. Linear regression analysis is used as analysis technique. This research concluded that company's profit/loss and reputation of public accountant firm negatively influenced on audit delay. Company size didn't affect to audit delay. Company's operations complexity was no conclusion.
\end{abstract}

Keywords :audit delay, company size, company's profit/loss, company's operations complexity, reputation of public accountant firm.

\begin{abstract}
Latar belakang dari penelitian ini adanya hasil yang tidak konsisten pada variabel yang memengaruhi audit delay. Selain itu, pada tahun 2015 adanya beberapa perusahaan yang disuspensi oleh BEI karena telat menyampaikan laporan keuangan. Penelitian ini bertujuan untuk meneliti pengaruh ukuran perusahaan, laba/rugi perusahaan, kompleksitas operasi perusahaan, dan reputasi KAP terhadap audit delay. Penelitian ini dilakukan pada perusahaan pertambangan di Bursa Efek Indonesia tahun 2012-2014. Purposive sampling digunakan sebagai metode dalam pengambilan sampel dan didapatkan jumlah sampel sebanyak 96 sampel. Teknik analisis yang digunakan adalah teknik analisis berganda. Penelitian ini menghasilkan kesimpulan bahwa laba/rugi perusahaan dan reputasi KAP berpengaruh negatif terhadap audit delay. Ukuran perusahaan tidak berpengaruh terhadap audit delay. Kompleksitas operasi perusahaan tidak dapat disimpulkan.
\end{abstract}

Kata kunci : audit delay, ukuran perusahaan, laba/rugi perusahaan, kompleksitas operasi perusahaan, reputasi KAP.

\section{Pendahuluan}

BEI (Bursa Efek Indonesia) melakukan suspensi pada 6 emiten, yaitu PT Benakat Integra Tbk. (BIPI), PT Borneo Lumbung Energi \& Metal Tbk. (BORN), PT Bumi Resources Tbk. (BUMI), PT Permata Prima Sakti Tbk.
(TKGA), PT Inovisi Infracom Tbk (INVS), dan PT Berau Coal Energy Tbk. (BRAU) karena 6 emiten tersebut belum menyampaikan laporan keuangannya hingga 30 Juni 2015. BEI melakukan suspensi apabila mulai hari kalender hari ke-91 sejak lampaunya batas waktu penyampaian laporan keuangan, 
perusahaan tercatat tidak memenuhi kewajiban (market.bisnis.com).

Batas waktu penyampaian laporan keuangan di Indonesia telah diatur oleh Badan Pengawas Pasar Modal (Bapepam). Menurut KEP-346/BL/2011, emiten atau perusahaan publik yang pernyataan pendaftarannya telah menjadi efektif wajib menyampaikan laporan tahunan kepada Bapepam dan LK paling lama tiga bulan setelah tahun buku berakhir.

Laporan keuangan menggambarkan dampak keuangan dari transaksi dan peristiwa lain yang diklasifikasikan dalam beberapa kelompok besar menurut karakteristik ekonominya. Kelompok besar ini merupakan unsur laporan keuangan. Unsur yang berkaitan secara langsung dengan pengukuran posisi keuangan adalah asset, liabilitas, dan ekuitas. Sedang unsur yang berkaitan dengan pengukuran kinerja laporan laba rugi adalah penghasilan dan beban (Kerangka Dasar Penyusunan dan Penyajian Laporan Keuangan pada PSAK No.1 (2012:9)).

Karakteristik kualitatif laporan keuangan adalah dapat dipahami, relevan, keandalan, dan dapat diperbandingkan. Salah satu indikator laporan keuangan yang relevan adalah tepat waktu, jika terdapat penundaan yang tidak semestinya dalam pelaporan, maka informasi yang dihasilkan akan kehilangan relevansinya. Agar bermanfaat, informasi harus relevan untuk memenuhi kebutuhan pengguna dalam proses pengambilan keputusan. Informasi memiliki kualitas relevan kalau dapat memengaruhi keputusan ekonomi pengguna dengan membantu mereka mengevaluasi peristiwa masa lalu, masa kini atau masa depan, menegaskan, atau mengoreksi, hasil evaluasi pengguna masa lalu (Kerangka Dasar Penyusunan dan Penyajian Laporan Keuangan pada PSAK No.1 (2012:5)).

Menurut Ashton et al., 1987, penyampaian laporan keuangan dapat dipengaruhi oleh audit delay. Audit delay merupakan keterlambatan penyelesaian audit yang dapat dihitung melalui selisih antara tanggal ditandatanganinya laporan auditor independen dengan tanggal tutup buku laporan keuangan tahunan. Ketelitian dan kecermatan disertai dengan mengumpulkan alat bukti yang cukup dan memadai harus dilakukakn dalam proses audit. Hal ini didasarkan pada Standar Pemeriksaan Akuntan Publik yaitu pada standar ketiga, sehingga menyebabkan dapat terjadinya perpanjangan masa pekerjaan lapangan dan negosiasi dengan pihak manajemen atas temuannya sehingga auditor dapat menunda publikasi atas laporan keuangan dan laporan auditor independen.

Menurut penelitian sebelumnya, terdapat banyak faktor yang dapat menyebabkan audit delay. Namun, selama ini masih terdapat hasil yang tidak konsisten antara penelitian yang satu dengan lainnya. Menurut hasil penelitian Kartika (2011), ukuran perusahaan berpengaruh negatif terhadap audit delay. Sebab, manajemen dengan skala besar cenderung diberikan insentif untuk mempercepat penerbitan laporan keuangan auditan disebabkan perusahaan berskala besar dimonitor secara ketat oleh investor, pengawas permodalan dan pemerintah sehingga cenderung menghadapi tekanan eksternal yang lebih tinggi untuk mengumumkan laporan keuangan auditan lebih awal. Jadi, semakin besar ukuran perusahaan, maka audit delaynya semakin pendek. Hal ini tidak sejalan dengan hasil penelitian Puspitasari dan Sari (2012) yang menyatakan bahwa ukuran perusahaan berpengaruh positif terhadap audit delay. Semakin besar ukuran perusahaan maka semakin panjang audit delaynya.

Menurut Iskandar dan Trisnawati (2010), perusahaan yang menderita kerugian akan meminta auditornya untuk menjadwalkan kembali pengauditan lebih lambat dari biasanya sehingga menunda untuk mengumumkan "bad news" kepada publik. Auditor juga cenderung berhatihati dalam prosedur-prosedur audit yang memastikan nilai kerugian sehingga dengan demikian proses audit akan semakin panjang. Pernyataan ini tidak sesuai dengan hasil penelitian Prabowo 
dan Marsono (2013) yang menyatakan bahwa laba/rugi perusahaan tidak berpengaruh terhadap audit delay.

Menurut Che-Ahmad (2008), jumlah anak perusahaan yang dimiliki perusahaan mencerminkan bahwa perusahaan memiliki unit operasi yang lebih banyak yang harus diperiksa dalam setiap transaksi dan catatan yang menyertainya, sehingga auditor memerlukan waktu lebih lama untuk melakukan pekerjaan auditnya.Hal ini tidak sejalan dengan hasil penelitian Angruningrum dan Wirakusuma (2013) yang menyatakan bahwa kompleksitas operasi perusahaan tidak berpengaruh terhadap audit delay.

Penelitian Puspitasari dan Sari (2012) menyatakan bahwa reputasi KAP berpengaruh negatif dan signifikan terhadap audit delay. Hasil ini menunjukkan bahwa auditor yang tergabung dalam KAP the big four akan memberikan kualitas pekerjaan audit yang efektif dan efisien, sehingga audit dapat diselesaikan secara tepat waktu. Hasil penelitian ini tidak sesuai dengan penelitian Angruningrum dan Wirakusuma (2013) yang menyatakan bahwa reputasi KAP tidak berpengaruh terhadap audit delay.

\section{Perumusan Masalah}

Rumusan masalah yang akan dibahas dalam penelitian ini adalah apakah ukuran perusahaan, laba/rugi perusahaan, kompleksitas operasi perusahaan, dan reputasi KAP berpengaruhterhadap audit delay pada perusahaan pertambangan yang terdaftar di BEI periode 2012-2014.

\section{Tujuan dan Manfaat Penelitian}

Tujuan penelitian ini adalah untuk mengetahui apakah ukuran perusahaan, laba/rugi perusahaan, kompleksitas operasi perusahaan, dan reputasi KAP berpengaruhterhadap audit delay.

Manfaat penelitian ini adalah untuk memberikan informasi dan memotivasi dalam menyampaikan laporan keuangan tepat waktu bagi perusahaan, sebagai informasi yang digunakan untuk mengambil keputusan bagi investor, sebagai bahan pembanding jika ingin mengadakan penelitian lebih lanjut mengenai audit delay bagi pembaca, dan meningkatkan pemahaman pengaruh ukuran perusahaan, laba/rugi perusahaan, kompleksitas operasi perusahaan, dan reputasi KAP terhadap audit delay bagi penulis.

\section{Telaah Pustaka}

1. Teori Sinyal

Menurut Susilowati dan Turyanto (2011:21), signalling theory membahas bagaimana seharusnya sinyal-sinyal keberhasilan atau kegagalan managemen (agent) disampaikan kepada pemilik modal (principle).Penyampaian laporan keuangan dapat dianggap sebagai sinyal yang dapat menunjukkan apakah agen telah berbuat sesuai dengan kontrak atau belum. Teori sinyal juga mengemukakan tentang bagaimana seharusnya sebuah perusahaan memberikan sinyal kepada pengguna laporan keuangan. Sinyal tersebut berupa informasi mengenai kondisi perusahaan kepada pemilik ataupun pihak yang berkepentingan. Sinyal yang diberikan dapat juga dilakukan melalui pengungkapan informasi akuntansi seperti laporan keuangan, laporan apa yang sudah dilakukan oleh manajemen untuk merealisasikan keinginan pemilik, atau bahkan dapat berupa promosi serta informasi lain yang menyatakan bahwa perusahaan tersebut lebih baik dari pada perusahaan lain.

2. Laporan Keuangan

Laporan keuangan menurut Ikatan Akuntan Indonesia dalam Kerangka Dasar Penyusunan dan Penyajian Laporan Keuangan pada Standar Akuntansi Keuangan (2012:1) adalah : 
"Laporan keuangan merupakan bagian dari proses pelaporan keuangan. Laporan keuangan yang lengkap biasanya meliputi neraca, laporan laba rugi, laporan perubahan posisi keuangan(yang dapat disajikan dalam berbagai cara seperti misalnya sebagai laporan arus kas atau laporan arus dana), catatan dan laporan lain, serta materi penjelasan yang merupakan bagian integral dari laporan keuangan. Di samping itu juga termasuk skedul dan informasi tambahan yang berkaitan dengan laporan tersebut, misalnya informasi keuangan segmen industri dan geografis serta pengungkapan pengaruh perubahan harga."

3. Auditing

Arens et al. (2015:2) menyatakan definisi auditing sebagai berikut,

"Pengumpulan dan evaluasi bukti tentang informasi untuk menentukan dan melaporkan tingkat kesesuaian antara informasi itu dan kriteria yang telah ditetapkan."

Sehingga dapat disimpulkan
bahwa pengumpulan dan evaluasi bukti tentang informasi informasi untuk menentukan dan melaporkan tingkat kesesuaian antara informasi itu dan kriteria yang telah ditetapkan dengan tujuan untuk memberikan pendapat atas informasi tersebut yang dapat meningkatkan keyakinan pengguna laporan keuangan. Dalam melaksanakan audit, auditor harus kompeten dalam mengetahui jenis serta jumlah bukti yang akan dikumpulkan guna mencapai kesimpulan yang tepat setelah memeriksa bukti itu dan memiliki sikap mental independen.

4. Laporan Audit (Audit Report)

Kartika (2011:156) menyatakan bahwa laporan audit merupakan media yang dipakai oleh auditor dalam berkomunikasi dengan masyarakat lingkungannya. Dalam laporan tersebut auditor menyatakan pendapatnya mengenai kewajaran laporan keuangan auditan. Pendapat auditor tersebut disajikan dalam suatu laporan tertulis yang umumnya berupa laporan audit baku yang terdiri dari tiga paragraf yaitu paragraf pengantar (introductory paragraph), paragraf lingkup (scope paragraph), dan paragraf pendapat (opinion paragraph).

5. Audit Delay

Menurut Kartika (2011:155) audit delay merupakan rentang waktu penyelesaian audit yang diukur dari tanggal penutupan tahun buku sampai dengan tanggal diterbitkannya laporan audit. Ketepatan waktu penyusunan atau pelaporan suatu laporan keuangan perusahaan bisa berpengaruh pada nilai laporan keuangan tersebut. Keterlambatan informasi akan menimbulkan reaksi negatif dari pelaku pasar modal. Informasi laba yang dihasilkan perusahaan dijadikan sebagai salah satu dasar pengambilan keputusan untuk membeli atau menjual kepemilikan yang dimiliki oleh investor. Artinya, informasi yang dipublikasikan tersebut akan menyebabkan kenaikan atau penurunan harga saham.

6. Ketepatwaktuan (Timeliness)

Timeliness merupakan pemberian informasi kepada pembuat keputusan sebelum informasi itu kehilangan kapasitasnya/ kemampuannya untuk memengaruhi keputusan penggunanya. Apabila mendapatkan suatu informasi lebih awal maka informasi tersebut akan meningkatkan kapasitasnya/ kemampuannya untuk memengaruhi keputusan penggunanya, begitu juga sebaliknya jika terjadi keterlambatan dalam mendapatkan informasi, maka informasi tersebut kehilangan nilai kegunaannya untuk memengaruhi keputusan penggunanya (Kieso et al., 2011:47). 
7. Peraturan Kewajiban Penyampaian Laporan Keuangan

Kewajibanpenyampaian laporan keuangan berkala emiten atau perusahaan publik diatur dalam peraturan nomor X.K.2 yang ditetapkan dalam keputusan ketua Badan Pengawas Pasar Modal dan Lembaga Keuangan nomor KEP 346/BL/2011. Di dalam peraturan ini ditetapkan beberapa aturan, berikut adalah peraturan untuk laporan keuangan tahunan:

a. Laporan keuangan tahunan wajib disajikan secara perbandingan dengan periode yang sama tahun sebelumnya.

b. Laporan keuangan tahunan wajib disertai dengan laporan akuntan dalam rangka audit atas laporan keuangan.

c. Laporan keuangan tahunan wajib disampaikan kepada Bapepam dan LK dan diumumkan kepada masyarakat paling lambat pada akhir bulan ketiga setelah tanggal laporan keuangan tahunan.

d. Dalam hal emiten atau perusahaan publik telah menyampaikan laporan tahunan sebagaimana dimaksud dalam Peraturan Nomor X.K.6 sebelum batas waktu penyampaian laporan keuangan tahunan, maka emiten atau perusahaan publik tersebut tidak diwajibkan menyampaikan laporan keuangan tahunan secara tersendiri.

e. Pengumuman laporan keuangan tahunan sebagaimana dimaksud dalam huruf $\mathrm{c}$ wajib dilakukan dalam paling sedikit satu surat kabar harian berbahasa Indonesia yang berperedaran nasional, dengan ketentuan sebagai berikut:

1) laporan keuangan tahunan yang diumumkan paling sedikit meliputi laporan posisi keuangan (neraca), laporan laba rugi komprehensif, laporan arus kas, dan opini dari Akuntan,

2) bentuk dan isi laporan sebagaimana dimaksud dalam butir 1) wajib sama dengan yang disajikan dalam laporan keuangan tahunan yang disampaikan kepada Bapepam dan LK, dan

3) bukti pengumuman tersebut wajib disampaikan kepada Bapepam dan LK paling lambat 2 (dua) hari kerja setelah tanggal pengumuman.

8. Ukuran Perusahaan

Penelitian yang dilakukan oleh Puspitasari dan Sari (2012) menunjukkan bahwa ukuran perusahaan berpengaruh positif terhadap audit delay. Perusahaan dengan skalayang lebih besar akan menyelesaikan audit lebih lama dibandingkan dengan perusahaan yang berskala lebih kecil, dikarenakan jumlah sampel yang harus diambil semakin banyak dan semakin banyaknya prosedur audit yang harus ditempuh.

\section{Ha1 : Ukuran perusahaan berpengaruh positif terhadap audit delay.}

9. Laba/Rugi Perusahaan

Laba atau rugi perusahaan merupakan gambaran atas kinerja manajerial perusahaan dalam setahun. Di samping mendukung good news atau bad news, laba/rugi perusahaan dapat memengaruhi psikologis auditor. Efek psikologis auditor saat melakukan audit pada perusahaan yang mengalami rugi dapat menyebabkan audit delay semakin panjang. Auditor cenderung melakukan prosedur yang lebih ketat dan melakukan pengecekan ulang serta lebih kritis dalam menggunakan data sampel perusahaan yang mengalami kerugian. Jadi perusahaan yang mendapat laba akan memperpendek audit delay (Puspita Sari dan Sari, 2012).

$\mathrm{Ha}_{2}$ : Laba/rugi perusahaan berpengaruh negatif terhadap audit delay.

10. Kompleksitas Operasi Perusahaan Menurut Che-Ahmad (2008) dalam Angruningrum (2013), jumlah anak perusahaan yang dimiliki 
perusahaan mencerminkan bahwa perusahaan memiliki unit operasi yang lebih banyak yang harus diperiksa dalam setiap transaksi dan catatan yang menyertainya. Perusahaan yang memiliki anak perusahaan, waktu yang diperlukan auditor untuk melakukan pekerjaan auditnya lebih lama.

$\mathrm{Ha}_{3}$ : Kompleksitas operasi perusahaan berpengaruh positif terhadap audit delay.

\section{Reputasi KAP}

KAP yang besar (Big Four) cenderung untuk menyelesaikan proses audit klien lebih cepat karena adanya insentif yang lebih besar dan struktur kerja yang baik dalam KAP tersebut. KAP yang besar (Big Four) akan mempertahankan kualitas kerjanya terhadap klien untuk menjaga reputasinya. Kualitas auditan berpengaruh terhadap kredibilitas laporan keuangan ketika perusahaan go public (Kartika, 2011). Sehingga perusahaan yang di audit oleh KAP big four akanmemperpendek audit delaynya.

$\mathrm{Ha}_{4}$ : Reputasi KAP berpengaruh negatif terhadap audit delay.

\section{Metodologi Penelitian}

Objek dalam penelitian ini adalah perusahaan pertambangan di Bursa Efek Indonesia tahun 2012-2014. Penelitian ini menggunakan data sekunder yang diperoleh dari www.idx.co.id dan IDX Watch.

Definisi Operasional Variabel dan Pengukuran Variabel Penelitian

1. Variabel Dependen

Variabel dependen yang digunakan dalam penelitian ini adalah audit delay. Variabel ini diukur berdasarkan interval atau jumlah hari antara tanggal tutup buku perusahaan yaitu 31 Desember sampai dengan tanggal laporan auditor ditandatangani.
2. Variabel Independen

a. Ukuran Perusahaan

Variabel ukuran perusahaan diproksikan dengan logaritma natural dari total aset.

Ukuran

Perusahaan= logaritma natural (total aset)

b. Laba/Rugi Perusahaan

Variabel ini diukur dengan dummy yaitu untuk perusahaan yang mengalami laba diberi kode dummy 1 dan yang mengalami rugi diberi kode dummy 0.

c. Kompleksitas Operasi Perusahaan

Variabel ini diukur dengan membandingkan keberadaan anak perusahaan. Variabel dummy dalam pengukuran ini, apabila memiliki anak perusahaan akan menggunakan kode 1 dan 0 bagi perusahaan yang tidak memiliki anak.

d. Reputasi KAP

Reputasi KAP diukur dengan menggunakan variabel dummy, kode 0 untuk KAP non big four dan kode 1 untuk KAP big four.

\section{Populasi dan Sampel}

Metode pengambilan sampel dilakukan dengan menggunakan sampelnon probabilitas, yaitu metode purposive sampling, dimana sampel dipilih untuk dapat mewakili populasi dengan kriteria tertentu sesuai dengan tujuan penelitian. Kriteria dalam pemilihan sampel, yaitu perusahaan pertambanganyang terdaftar (listing) di Bursa Efek Indonesia tahun 2012-2014, perusahaan yang tidak mengalami delisting selama tahun pengamatan, dan perusahaan yang memiliki data untuk semua variabel.

\section{Teknik Analisis Data}

Adapun langkah-langkahnya sebagai berikut : 
1. Uji kesamaan koefisien (comparing two regression, the dummy variable approach) dilakukan untuk mengetahui apakah pooling data penelitian (penggabungan data cross sectional dengan time-series) dapat dilakukan.

2. Statistik deskriptif mendeskripsikan data menjadi sebuah informasi yang lebih jelas dan mudah dipahami. Untuk mengetahui rata-rata, nilai minimum dan maksimum, dan standar deviasi dari setiap variabel yang diteliti, maka digunakan statistik deskriptif.

3. Uji asumsi klasik untuk mengetahui apakah data dapat mewakili populasi. Terdapat 4 asumsi klasik, yaitu:uji normalitas (One-Sample KolmogorovSmirnov Test), uji heteroskedastisitas (Spearman's Rho), uji multikolinearitas, dan uji autokolerasi (Durbin Watson).

4. Analisis regresi berganda digunakan untuk meneliti hubungan antara sebuah variabel dependen dengan beberapa variabel independen. Model yang digunakan dalam regresi berganda adalah sebagai berikut:

$$
\begin{aligned}
& \text { AUDEL }=\alpha+\beta 1 \text { UKPER }+ \\
& \beta 2 \text { PROFIT }+\beta 3 \text { KOMPLEK }+ \\
& \beta 4 \text { KAP }+\varepsilon
\end{aligned}
$$

\begin{tabular}{|c|c|}
\hline Keterangan & \\
\hline AUDEL & $=$ Audit Delay \\
\hline $\begin{array}{l}\text { UKPER } \\
\text { Perusahaan }\end{array}$ & $=\quad$ Ukuran \\
\hline $\begin{array}{l}\text { PROFIT } \\
\quad \text { Perusahaan }\end{array}$ & Laba/Rugi \\
\hline KOMPLEK & Kompleksitas \\
\hline Operasi Per & \\
\hline $\begin{array}{l}\text { KAP } \\
\alpha\end{array}$ & $\begin{array}{l}=\text { Reputasi KAP } \\
=\text { Konstanta }\end{array}$ \\
\hline$\beta$ & $=\quad$ Koefisien \\
\hline & $=$ Error \\
\hline
\end{tabular}

\section{Hasil Dan Pembahasan \\ Deskripsi Sampel Penelitian}

Obyek penelitian dalam penelitian ini adalah perusahaan pertambangan yang terdaftar di BEI pada tahun 2012-2014. Data diperoleh dari www.idx.co.id dan IDX Watch yang berjumlah 38 perusahaan. Pengambilan sampel dilakukan dengan metode purposive sampling sehingga yang dijadikan sampel hanya 32 perusahaan (96 perusahaan).

\section{Hasil Penelitian}

1. Pengaruh Ukuran Perusahaan terhadap Audit Delay

Berdasarkan uji $t$ yang dilakukan, variabelukuran perusahaan (UKPER) memiliki koefisien regresi 1.567 dengan nilai signifikansi sebesar 0.15. Hasil ini menunjukkan bahwa ukuran perusahaan tidak terbukti berpengaruh terhadap audit delay dan memiliki hubungan yang positif terhadap audit delay. Berdasarkan hasil tersebut maka dapat disimpulkan bahwaukuran perusahaantidak memengaruhi waktu audit delay. Hal ini tidak sesuai dengan hipotesis penelitian yang mengatakan bahwa ukuran perusahaan berpengaruh positif terhadap audit delay. Namun, hal ini sejalan dengan penelitian Iskandar dan Trisnawati (2010) yang menyatakan bahwa walaupun total aset perusahaan beragam bukan berarti tidak memiliki internal control yang baik dan kemampuan untuk menekan auditornya agar menyelesaikan tugas auditnya secara tepat waktu.

2. Pengaruh Laba/Rugi Perusahaan terhadap Audit Delay

Berdasarkan hasil pengujian didapatkan, variabellaba/rugi perusahaan(PROFIT) memiliki koefisien regresi -11.857 dengan nilai signifikansi sebesar 0.018. Hasil ini menunjukkan bahwa laba/rugi perusahaan terbukti berpengaruh negatif terhadap audit delay. Hal ini sesuai dengan hipotesis penelitian 
yang mengatakan laba/rugi perusahaan berpengaruh negatif terhadap audit delay. Berdasarkan hasil tersebut maka dapat disimpulkan bahwa laba/rugi perusahaan mempercepat waktu audit delay, sehingga perusahaan akan lebih cepat dalam memberikan sinyal kepada investor. Hal ini sesuai dengan penelitian Puspita Sari dan Sari (2012) yang menyatakan bahwa perusahaan yang memperoleh laba akan mendukung good news dan ingin segera mempublikasikan laporan keuangannya. Sedangkan perusahaan yang merugi cenderung akan memperpanjang audit delay, karena auditor cenderung melakukan prosedur yang lebih ketat dan melakukan pengecekan ulang serta lebih kritis dalam menggunakan data sampel perusahaan yang mengalami kerugian.

3. Pengaruh Kompleksitas Operasi Perusahaan Terhadap Audit Delay

Berdasarkan hasil pengujian didapatkan, variabelkompleksitas operasi perusahaan(KOMPLEK) memiliki koefisien regresi -10.726 dengan nilai signifikansi sebesar 0.025 . Hasil ini menunjukkan bahwa kompleksitas operasi perusahaan tidak terbukti berpengaruh positif terhadap audit delay. Berdasarkan hasil tersebut maka dapat disimpulkan bahwa kompleksitas operasi perusahaan mempercepat waktu audit delay, sehingga perusahaan akan lebih cepat dalam memberikan sinyal kepada investor. Tetapi hasil penelitian tidak sesuai dengan hipotesis penelitian yang menyatakan kompleksitas operasi perusahaan berpengaruh positif terhadap audit delay. Hal ini dikarenakan perusahaan yang memiliki anak perusahaan pada umumnya memiliki kontrol internal yang baik.

4. Pengaruh Reputasi KAP Terhadap Audit Delay
Berdasarkan hasil pengujian didapatkan, variabelreputasi KAP (KAP) memiliki koefisien regresi12.677 dengan nilai signifikansi sebesar 0.006. Hasil menunjukkan bahwa reputasi KAP terbukti berpengaruh negatif terhadap audit delay. Hal ini sesuai dengan hipotesis penelitian yang mengatakan reputasi KAP berpengaruh negatif terhadap audit delay. Berdasarkan hasil tersebut maka dapat disimpulkan bahwa reputasi KAP mempercepat waktu audit delay, sehingga perusahaan akan lebih cepat dalam memberikan sinyal kepada investor. Hal ini sesuai dengan penelitian Kartika (2011), yang menyatakan bahwa KAP yang besar (Big Four) cenderung untuk menyelesaikan proses audit klien lebih cepat karena adanya insentif yang lebih besar dan struktur kerja yang baik dalam KAP tersebut. KAP yang besar (Big Four) akan mempertahankan kualitas kerjanya terhadap klien untuk menjaga reputasinya.

\section{Kesimpulan dan Saran}

\section{Kesimpulan}

Ukuran perusahaan tidak terbukti berpengaruh terhadap audit delay dan mempunyai hubungan yang positif terhadap audit delay. Laba/rugi perusahaan dan reputasi KAP terbukti berpengaruh negatif terhadap audit delay. Kompleksitas operasi perusahaan tidak terbukti berpengaruh positif terhadap audit delay, sehingga tidak dapat disimpulkan.

\section{Saran}

Bagi perusahaan:

1. Mempersiapkan laporan keuangan selengkap dan secepat mungkin tanpa ada manipulasi sesuai dengan standar yang berlaku umum, sehingga proses audit dapat berjalan lancar dan lebih cepat.

Bagi peneliti selanjutnya: 
1. Menambah variabel independen, seperti audit tenure.

2. Menggunakan periode waktu yang lebih lama dan memperluas sampel yang digunakan agar pengaruhnya lebih terlihat dengan jelas.

\section{DAFTAR PUSTAKA}

Angruningrum, Silvia dan Made Gede Wirakusuma (2013), Pengaruh Profitabilitas, Leverage, Kompleksitas Operasi, Reputasi KAP, dan Komite Audit Pada Audit Delay, ISSN: 2302-8556 E-Jurnal Akuntansi Universitas Udayana 5.2, Hal: 251-270.

Annual Report, diakses 1 Januari 2016, http://www.idx.co.id/.

Arens, Alvian A, Randal J.Elder, Mark S. Beasley (2015), Auditing dan Jasa Assurance: Pendekatan Terintegrasi, Edisi Kelimabelas, Jilid 1, Terjemahan oleh Herman Wibowo, Jakarta, Penerbit Erlangga.

Ashton, R., Wilingham, J., \& Elliot, R. (1987), An Empirical Analysis of Audit Delay, Journal of Accounting Research, Vol. 25, No. 2, Hal: 275292.

Badan Pengawas Pasar Modal (2011). Peraturan Nomor X.K.2. Penyampaian Laporan Keuangan Berkala Emiten Atau Perusahaan Publik. Lampiran Keputusan Ketua Bapepam Nomor KEP346/BL/2011 tanggal 5 Juli 2011.

Bisnis Indonesia (2012), diakses
Desember
http://market.bisnis.com/
read/2015,
suspensi-6-emiten.-born-bumi-
brau-termasuk.

Che-Ahmad, Ayoib and Shamharir Abidi (2008), Audit Delay of Listed Companies: A Case of Malaysia,International Business Reseach, Vol. 1, No. 4.

Cooper, Donald R. dan Pamela S. Schindler (2014), Business Research Methods, Edisi 12, International Edition, Singapore : McGraw-Hill.

Ghozali, Imam (2012), Aplikasi Analisis Multivariate dengan Program IBM SPSS 20, Semarang: Badan Penerbit Universitas Diponegoro.

Ikatan Akuntansi Indonesia (2012), Kerangka Dasar Penyusunan Laporan Keuangan, Standar Akuntansi Keuangan, Jakarta: Salemba.

Iskandar, M. Januar dan Estralita T. (2010), Faktor-Faktor yang Mempengaruhi Audit Report Lag pada Perusahaan yang Terdaftar di Bursa Efek Indonesia, Jurnal Bisnis dan Akuntansi, Desember Vol 12, No. 3.

Kartika, Andi (2011), Faktor-Faktor Yang Mempengaruhi Audit Delay Pada Perusahaan Manufaktur Yang Terdaftar Di BEI, Dinamika Keuangan dan Perbankan, November Vol 3, No. 2.

Kieso, D. E. et al (2011), Intermediate Accounting, Volume 1, Edisi IFRS, Penerbit: John Wiley dan Sons.

Prabowo, P.P.T. dan Marsono (2013), Faktor-Faktor yang Mempengaruhi Audit Delay, Diponegoro Journal of Accounting, Vol 2, No.1.

Priyatno, Duwi (2010), Teknik Mudah dan Cepat Melakukan Analisis 
Data

Penelitian dengan SPSS dan Tanya Jawab Ujian Pendadaran, Yogyakarta: Gaya Media.

Puspitasari, Elen dan Anggraeni Nurmala S. (2012), Pengaruh Karakteristik Perusahaan terhadap Lamanya Waktu Penyelesaian Audit (Audit Delay) pada Perusahaan Manufaktur yang Terdaftar di
Bursa Efek Indonesia, Jurnal Akuntansi dan Auditing, November Vol 9, No. 1.

Susilowati, Yeye dan Tri Turyanto (2011), Reaksi Signal Profitabilitas dan Rasio Solvabilitas terhadap Return Saham Perusahaan, Jurnal Dinamika Keuangan dan Perbankan, Vol. 3, No. 1, Mei 2011:17-37, ISSN: 1979-4878. 

